\title{
An Evaluation of Range Condition on One Range Site in the Andes of Central Peru
}

\author{
BRADFORD P. WILCOX, F. C. BRYANT, AND VICTOR BELAUN FRAGA
}

\section{Abstract}

Little published information is available on the vegetation or its response to grazing in the high elevation $(3,900-4,800 \mathrm{~m})$ grasslands of the Andes, known as the puna. The objective of this study was to evaluate grazing-induced vegetation changes on a major range site in the puna. Basal cover and diversity were compared on (1) rangelands managed by a cooperative of land holders (moderate grazing); (2) communal grazing land (heavy grazing); and (3) sacrifice or holding pastures (very heavy grazing). Basal cover was determined using point transects. With increased grazing pressure standing height of the vegetation was greatly reduced as was vegetation basal cover. Total cover of grasses was reduced while forb cover increased. Ability of a species to grow close to the soil surface probably enabled it to tolerate very heavy grazing. Species diversity as determined by Simpson's D, Shannon-Weaver's H', and species richness was highest on the community lands.

\section{Key Words: plant succession, grazing effects, puna}

Livestock grazing can have a profound impact on range vegetation (Stoddart et al. 1975). The general pattern of grazing-induced vegetation change is well documented in the U.S. and much of North America. It is known that less palatable plants increase at

The authors are assistant professor in watershed management, Department of Earth Resources, Colorado State University, Fort Collins 80523; associate professor, Department of Range and Wildlife Management, Texas Tech University, Lubbock 79409; and research assistant, Corpacancha, Peru.

This research was carried out as part of the United States Agency for International Development Title XII, Small Ruminant Collaborative Research Support Program, under Grant DSAN/ XII-G-0049, in collaboration with Instituto Nacional de Investigacion y Promocion Agropecuaria, Peru. The authors wish to thank Universidad Nacional Agraria for their support, and Drs. Oscar Tovar and Emma Cerrate for assistance in plant identification. This is article T-9-465 of the College of Agricultural Sciences

Manuscript accepted 14 July 1986. the expense of the more palatable species. Community structure is vastly altered when improper grazing continues for long periods (Daubenmire 1968). Adams (1975) and Ellison (1960) presented reviews of the abundant literature available on the effects of grazing management on North American rangelands. Much less is known about South American rangelands, particularly the high elevation grassland of the Andes, known as the puna (Fig. 1).

These high elevation grasslands are important grazing lands for the Andean countries. The puna extends over many hundred thousands square kilometers from latitutes $8^{\circ} \mathrm{S}$ to $27^{\circ} \mathrm{S}$. The puna is associated with a series of high plateaus and intermontane basins beginning with the Pampa de Junin in central Peru. The altiplano, a tableland in southern Peru and Bolivia, is the most familiar of these plateaus. Elevation of the puna varies from about 3,900 to $4,800 \mathrm{~m}$. Troll (1968) divided the puna into 3 provinces: the moist puna, the dry puna, and the desert puna. The moist puna begins in northern Peru at about latitude $8^{\circ} \mathrm{S}$ where it blends in with another high elevation grassland typical of the northern Andes, the paramo, and lies adjacent to the eastern cordillera of the Andes as far south as Bolivia. The dry puna beings in southern Peru and extends into the altiplano of Boliva, while the desert puna occurs in southern Boliva and Chile adjacent to the Atacama Desert.

Precipitation in the puna is concentrated in a single wet season, between October and April, of variable length, and ranges from $150 \mathrm{~mm}$ in the desert puna to $1,200 \mathrm{~mm}$ per annum in the moist puna belt (Molina and Little 1981). Annual rainfall decreases to the south and west. There is also a steady increase in concentration of the rainfall period as one moves south (Johnson 1976). The mean annual temperatures are less than $10^{\circ} \mathrm{C}$ and nocturnal frosts are common, especially during the dry season (Troll 1968). Frost

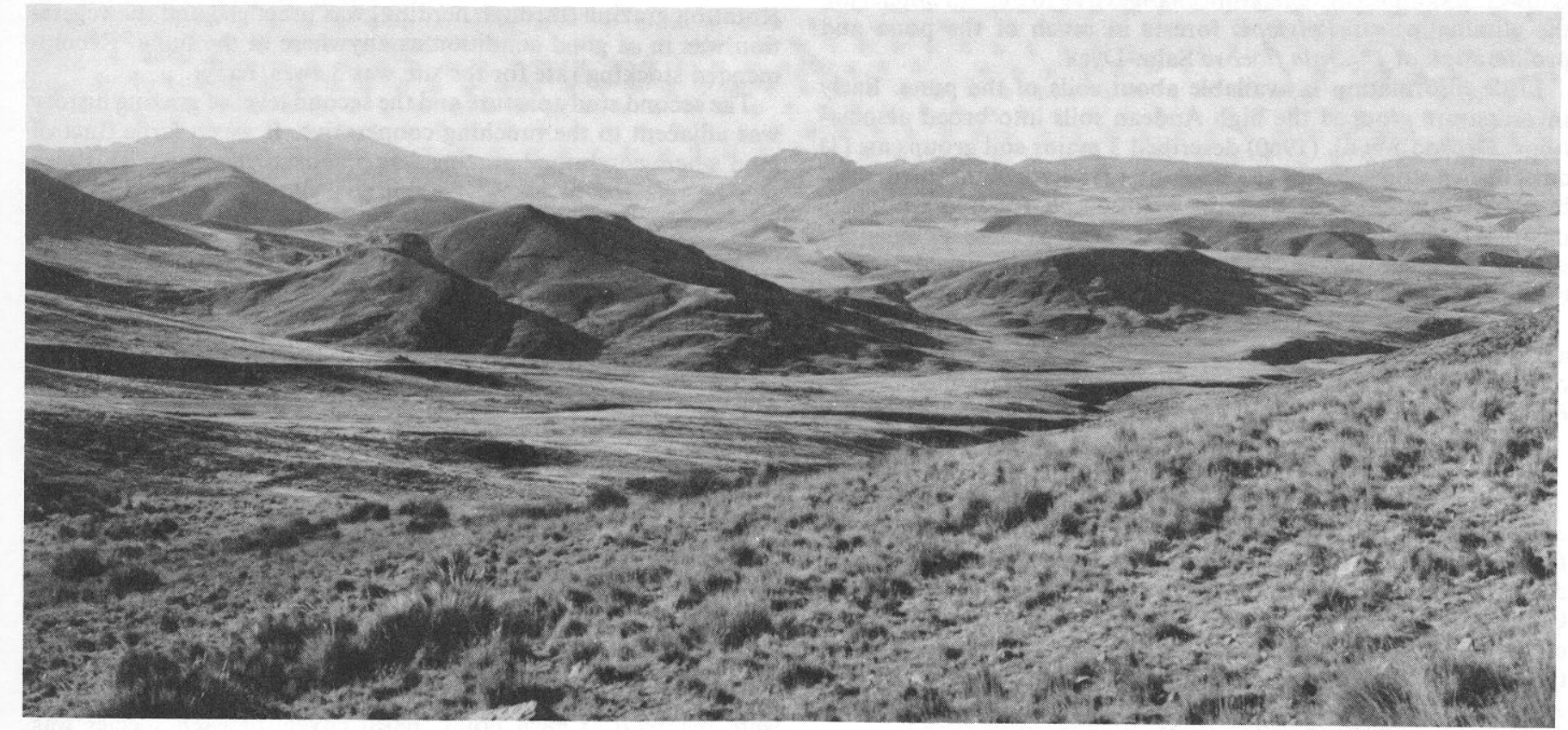

Fig. 1. The puna in the central Andes of Peru has a rugged topography and is dominated by cool-season grasses and forbs. Shrubs and trees are uncommon. 
occurs nightly at $4,100 \mathrm{~m}$. The diurnal season fluctuations can be as much as $20^{\circ} \mathrm{C}$ in the moist puna and even greater in the desert puna. The paramo grasslands are distinguished from the puna by the lack of seasonal differences in precipitation and temperature, and also by a higher relative humidity.

The puna vegetation has evolved under harsh environmental conditions, such as a lengthy dry season, frequent frosts, low temperatures, pronounced diurnal variation, high solar radiation, and low oxygen (Thomas and Winterhalder 1976). Plants have adapted to these environmental stresses in various ways (Cabrera 1968). Perennial forbs typically have well-developed root systems, many times larger than the aboveground portions of plants, and grow very close to the ground surface. Leaves are often reduced, felty, and lightly pubescent, or have a thick cuticle layer. Succulents such as Opuntia are also common. Many grasses have rolled leaves. Stems are often reduced or are below ground with only the leaves protruding above the surface.

Weberbauer (1936) distinguished 4 major vegetation formations in the moist puna: (1) puna mat, (2) bunchgrass, (3) Distichia moor, and (4) the vegetation of rocks and stone fields. The puna mat is composed predominantly of dwarf herbaceous forbs and cushion plants growing in areas of moderate water content. Tall grasses, erect shrubs, mosses, and lichens are of minor importance. The bunchgrass formation is the most extensive and composed chiefly of perennial grasses such as Festuca, Poa, Stipa and Calamogrostis species. Many of the forbs found in the puna mat also are present in the bunchgrass formation. The Distichia moor remains moist yearlong and Distichia muscoides Nees et Mey. is the characteristic plant. Vegetation of the rock and stone fields is distinctive in that lichens, mosses, ferns, erect shrubs, and tallstalked herbs occur more abundantly. Tufted grasses also are an important component. The radiated heat provided by the rocks allows his formation to extend up to $5,000 \mathrm{~m}$, while the other formations disappear around $4,600 \mathrm{~m}$. Weberbauer (1936) described this formation as a heat oasis, allowing certain plants to thrive which otherwise would not grow in the puna. He also noted scattered Polylepis groves, sometimes extending for several kilometers and growing up to the snowline.

Floristically the moist and dry puna are closely related. Evergreen shrubs are more common in the dry puna (Molina and Little 1981). In the desert puna shrubs predominate and vegetation cover is lower. Examples of vegetation changes due to human impact are the elimination of Polylepis forests in much of the puna and proliferation of Opuntia flocosa Salm-Dyck.

Little information is available about soils of the puna. Early investigators grouped the high Andean soils into broad associations. Drosdoff et al. (1960) described 3 major soil groups as: (1) dark brown stoney loams to silt loams, (2) deep well-drained, dark brown to black loams and silt loams, and (3) hydromorphic medium to fine texture soils. Beek and Bramao (1968) included the soils of the central Andes as Paramo soils, and described them as being derived from heavy clays of glacial origin.

The vegetation in the central Andes is poorly understood (Glaser and Celecia 1981) especially as regards responses to grazing. The objective of this study was to investigate the vegetation of a major range site in the moist puna belt under 3 different grazing regimes.

\section{Study Area and Methods}

The study area of approximately 17,700 ha was located on and adjacent to an agricultural cooperative, Sociadad Agricola de Interes Social (S.A.I.S.) Pachacutec, headquartered at Corpacancha in the Department of Junin, Peru (11 $25^{\prime} \mathrm{S}, 76^{\circ} 15^{\prime} \mathrm{W}$ ) (Fig. 2). Corpacancha is about $42 \mathrm{~km}$ ENE of La Oroya, Peru. Rangeland of the cooperative has historically received better management than most of the puna, much of which is severely overgrazed. The elevation ranges from $4,150 \mathrm{~m}$ to $4,700 \mathrm{~m}$. Topography is both gently rolling glaciated and rugged mountainous terrain.

Corpacancha is in the moist puna belt as classified by Troll (1968). Vallejos and Quillatupa (1975) reported that in Corpacan-

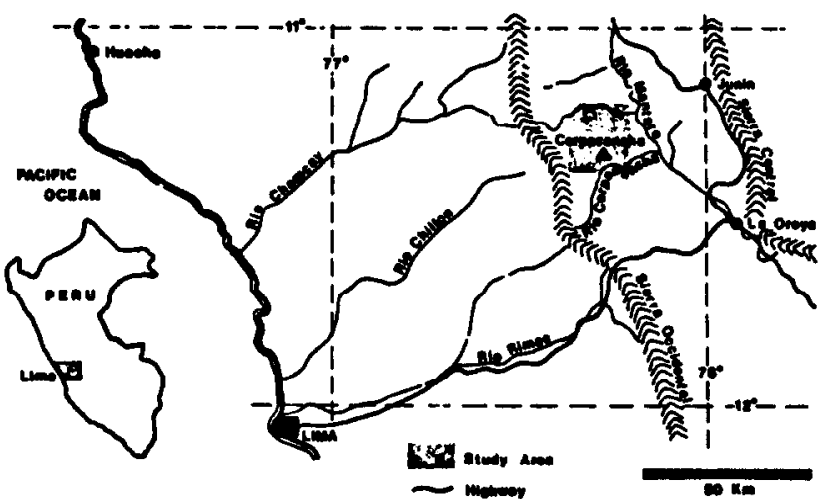

Fig. 2. Map of the study area in the central Andes of Peru.

cha, the average yearly precipitation from 1965 to 1972 was 865 $\mathrm{mm}$, and varied from $672 \mathrm{~mm}$ to $1,033 \mathrm{~mm}$. Snow makes up a small percentage of this precipitation and does not accumulate below the permanent snow line (Troll 1968), which begins at about $5,150 \mathrm{~m}$ (Thomas and Winterhalder 1976).

Wilcox (1982) delineated 8 range sites on the study area. All of them are dominated by cool-season mid to tall grasses. Common genera include Calamagrostis, Festuca, Poa, Stipa, and Muhlenbergia. Low growing forbs are also common. Trees are absent and shrubs are rare.

The range site selected for this research made up 50\% of the study area and occurs on the glaciated mountain valley slopes (Fig. 3). Soils developed on glacial till and are moderately deep (B horizon extends from $40-100 \mathrm{~cm}$ ). They also commonly exhibit umbric epipedons and argillic horizons. Organic carbon is around $6 \%$ in the upper sola and $\mathrm{pH}$ is between 4.5 and 6.0. Textures are loam in the A horizon and clay loam to gravelly clay loam in the B horizon. Often the soil is mantled by a thin organic horizon. Soils were classified as Mollic Cryoboralfs (Wilcox 1982).

Study pastures were representative of 3 levels of past grazing history. The first level occurred on the ranching cooperative at Corpacancha. Agricultural cooperatives are common in Peru. Workers have an active voice in the management of the cooperatives, but trained agriculturalists are employed as managers. Sheep and alpaca were the principal grazing animals on the cooperative. Rotation grazing (through herding) was practiced and the vegetation was in as good condition as anywhere in the puna. Recommended stocking rate for the site was 3 ewes/ha/yr.

The second study pasture and the second level of grazing history was adjacent to the ranching cooperative. It was a large tract of land where communal grazing was practiced year long. This area will be referred to as the community site. Based on a year of observation, it appeared to be more heavily grazed than the cooperative. Standing biomass was less as was standing height of the vegetation. Sheep and llama grazed the community site. Stocking rate information was not readily available.

A third level of grazing pressure occurred on the holding pasture of the cooperative. The pastures were sacrifice areas and were the most heavily grazed. Stocking was difficult to estimate because of the put-and-take nature of its use.

These different grazing intensities on the same range site provided an excellent opportunity for studying grazing-induced vegetation changes in the puna. The puna has been grazed by humankind's domestic livestock for over 10,000 years (Engel 1976). No part of it has been left undisturbed. Thus, no true relict areas were available for comparison.

Basal cover was estimated with the point sampling method (Goodall 1952). Point samples were recorded along 25-m transects at $0.5-\mathrm{m}$ intervals. Species name, bare-ground, rock, litter, or moss were recorded at each point. Basal cover for each species was calculated as the percentage of direct hits per transect.

The number of transects on the ranching cooperative, commun- 


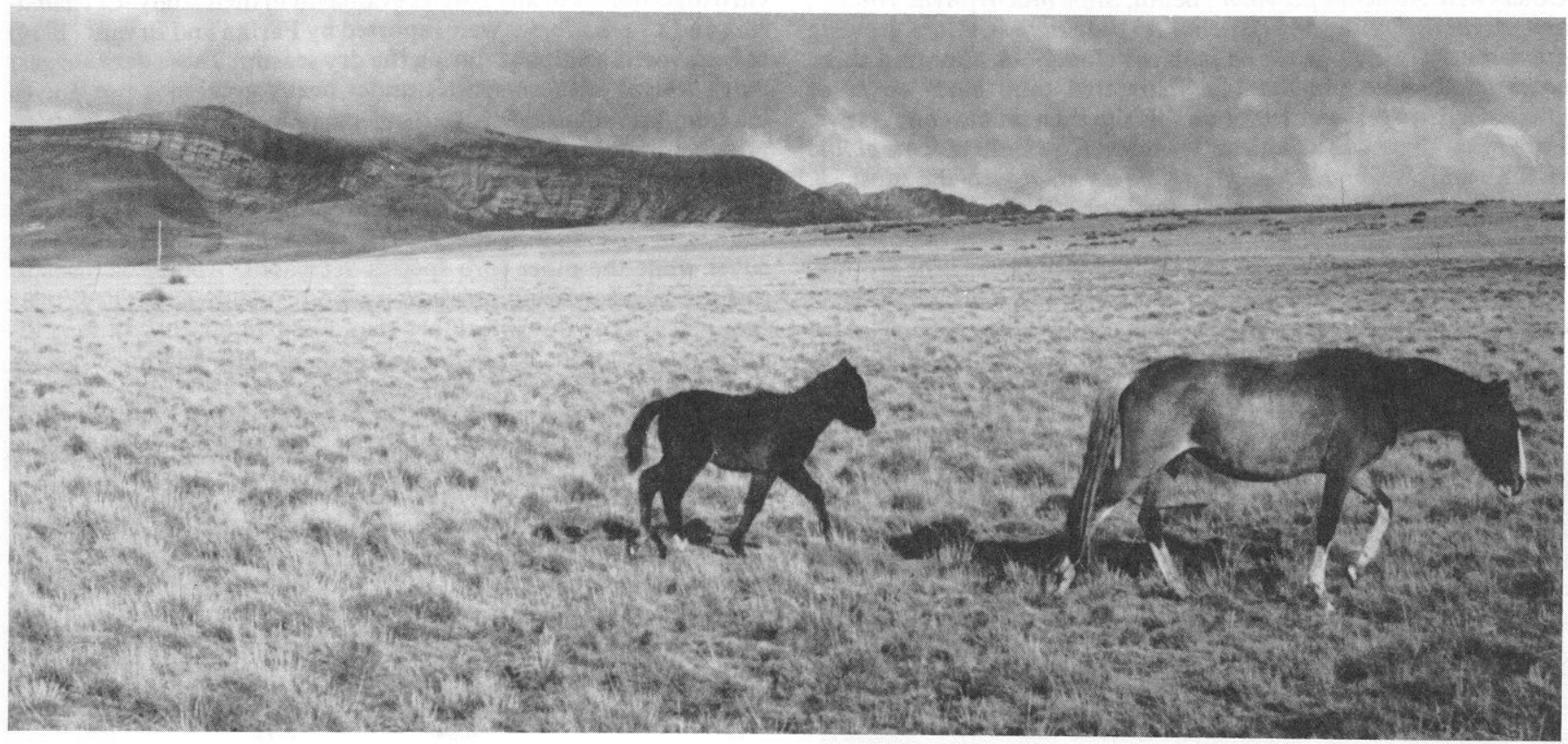

Fig. 3. The range site selected for study (foreground) was the most common range site in the study area.

ity site, and the holding pasture were $46,9,11$, respectively. The ranching cooperative was more heavily sampled because of associated vegetation inventory studies there (Wilcox 1982). The sampling intensity on the community lands and in the holding pasture was adequate to characterize basal cover. Wilcox (1982) used reciprocal averaging ordination to classify plant-community groups in the ranching cooperative. All 46 transects were closely grouped by reciprocal averaging analysis, and thus judged to be in the same plant community. Soil parent material, soil types, slope, and topographic position were similar on all sites sampled.

Shannon-Weaver's H' and Simpson's D diversity indices (GreigSmith 1964) were calculated for each grazing treatment. Simpson's $\mathrm{D}$ is most strongly influenced by abundance of dominant species. Rare species have little influence on it (Whittaker 1972). The Shannon-Weaver index is more strongly affected by the occurrence of intermediate and rare species (Whittaker 1972, Peet 1974). Both indices are independent of sample size if the sample size is adequate to represent the community (Whittaker 1972). Species richness values were calculated as the number of species occurring in each transect averaged across treatment.

Nomenclature of plant species follows that of McBride (1936), and Tovar $(1960,1965,1972)$. Species identification was confirmed at San Marcos University in Lima.

\section{Results and Discussion}

The dominant species on the ranching cooperative site was Festuca dolichophylla Presl, a common bunchgrass of the puna (Table 1). Typical height was about $60 \mathrm{~cm}$. Basal cover of $F$. dolichophylla was estimated to be 3 times that of the next most important species Calamagrostis vicunarum (Wedd.) Pilger, also a bunchgrass. $C$. vicunarum has much finer leaves and it is not as tall as $F$. dolichophylla. Other important species were Carex ecuadorica Kunth and Festuca rigescens Kunth. Both of the Festuca species are coarse grasses and have similar growth forms but $F$. dolichophylla grows taller. Forbs on the ranching cooperative made up less than $2 \%$ of the basal cover. Wilcox (1982) noted that generally forbs were less common as sites become more mesic. Alchemilla pinnata R. \& P. was the most abundant forb. Like many puna forbs this plant grows very close to the ground and has well developed roots.
Table 1. Basal cover (\%) and associated standard errors for the ranching cooperative, community lands, and holding pasture.

\begin{tabular}{|c|c|c|c|}
\hline & $\begin{array}{l}\text { Ranching } \\
\text { Cooperative }\end{array}$ & $\begin{array}{l}\text { Community } \\
\text { Land }\end{array}$ & $\begin{array}{l}\text { Holding } \\
\text { Pasture }\end{array}$ \\
\hline \multicolumn{4}{|l|}{ Grasses } \\
\hline Aciachne pulvinata & $1.4(0.4)$ & $2.9(1.3)$ & $0(0)$ \\
\hline Agrostis breviculumis & $0.6(0.2)$ & $3.3(0.8)$ & $2.4(0.8)$ \\
\hline Bromus lanatus & $1.0(0.2)$ & $0.2(0.2)$ & $0.4(0.4)$ \\
\hline Calamagrostis vicunarum & $4.4(0.6)$ & $4.2(0.9)$ & $1.8(0.6)$ \\
\hline Dissanthelium calycinum & $0.1(0.3)$ & $0.7(0.3)$ & $0.4(0.2)$ \\
\hline Festuca dolichophylla & $14.9(1.1)$ & $1.6(0.7)$ & $0(0)$ \\
\hline Festuca rigescens & $2.2(0.5)$ & $5.8(1.0)$ & $6.9(1.5)$ \\
\hline Hordeum muticum & $0.1(0.1)$ & $0.2(0.2)$ & $0(0)$. \\
\hline Muhlenbergia ligularis & $0.2(0.1)$ & $0.4(0.3)$ & $0.8(0.6)$ \\
\hline Poa candomoana & $0.4(0.2)$ & $0(0)$ & $0.6(0.3)$ \\
\hline Stipa brachyphylla & $0.4(0.1)$ & $1.6(0.6)$ & $0.6(0.5)$ \\
\hline Total grasses & $26.0(1.0)$ & $20.9(1.2)$ & $13.9(2.3)$ \\
\hline \multicolumn{4}{|l|}{ Forbs } \\
\hline Alchemilla pinnata & $0.4(0.1)$ & $0.8(0.5)$ & $1.8(0.7$ \\
\hline Baccharis alpina & $0.4(0.3)$ & $1.8(0.7)$ & $0.2(0.2)$ \\
\hline Geranium sessiliflorum & $0.1(0.1)$ & $0.4(0.3)$ & $0.4(0.2)$ \\
\hline Paronychia andina & $0.5(0.2)$ & $1.4(0.7)$ & $0.6(0.5)$ \\
\hline Total forbs & $1.8(0.5)$ & $5.3(1.1)$ & $6.0(1.6)$ \\
\hline \multicolumn{4}{|l|}{ Sedges } \\
\hline Carex ecuadorica & $2.6(0.4)$ & $2.2(0.7)$ & $1.6(0.7)$ \\
\hline Scirpus rigidus & $1.0(0.3)$ & $0(0)$ & $0(0)$ \\
\hline Total sedges & $3.6(0.5)$ & $2.2(0.3)$ & $1.8(0.7)$ \\
\hline Litter & $57.5(1.7)$ & $60.2(1.6)$ & $38.4(4.6)$ \\
\hline Bareground & $7.5(1.0)$ & $9.8(1.4)$ & $36.2(6.3)$ \\
\hline Moss & $3.3(0.7)$ & $1.1(1.8)$ & $3.7(1.2)$ \\
\hline Rock & $0.3(0.1)$ & $0.5(0.4)$ & 0 \\
\hline
\end{tabular}

Several vegetation differences were evident on the community site. The most obvious difference was the lower basal cover of $F$. dolichophylla. It was reduced from the dominant species to a common one. Basal cover was only $2 \%$ on this site while it was $15 \%$ on the ranching cooperative. No other species was so affected. $C$. vicunarum and $C$. ecuadorica remained about the same. Several 
species had higher basal cover estimates, most notably $F$. rigescens. Others were Aciachne pulvinata Benth, Stipa brachyphylla Hitchc., and Agrostis breviculmis Hitchc. A. pulvinata is a low growing grass species which grows in isolated clumps. It appeared to be coarse and quite unpalatable. Estimated total basal cover of grasses and sedges were lower on this site than on the cooperative. Forb basal cover was significantly higher. Cover of Bacharis alpina H.B.K. and Paronychia andina A. Gray increased the most. B. alpina is a spreading prostrate semishrub whose stems grow just under the soil surface, leaving only its small leaves exposed. $P$. andina is also a spreading species which grows close to the ground.

The vegetation in the holding pasture was only a few centimeters above the ground and in general was of low vigor (Fig. 4). Also

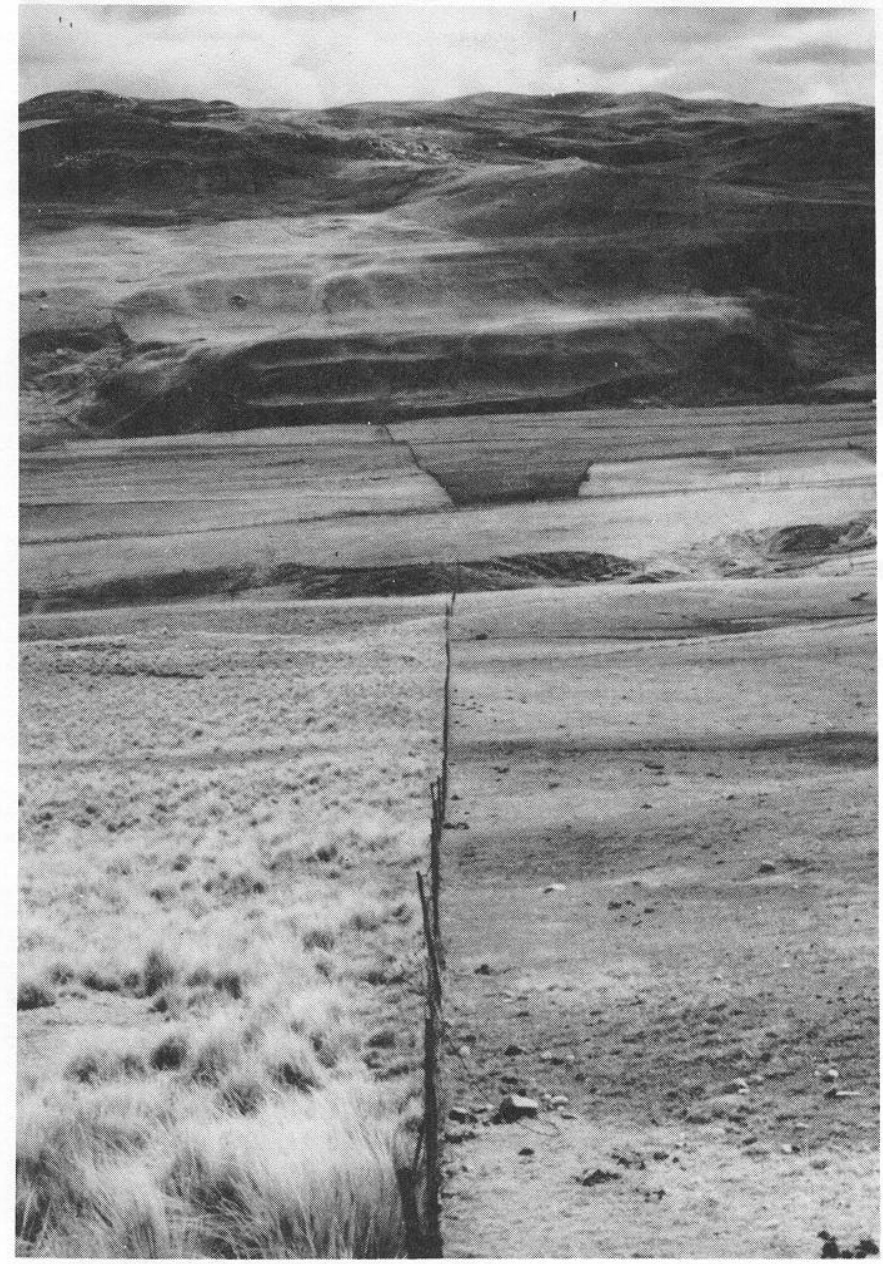

Fig. 4. Heavy grazing in the puna reduces the bunchgrass vegetation to decumbant grasses and forbs.

much more ground was exposed than in the other 2 areas. One cannot be absolutely certain that $F$. dolichophylla was eliminated from the holding pasture or that $F$. rigescens increased slightly. These species are difficult to separate from one another in the field if they are in a stunted condition, as they were, induced by the extreme grazing. No grass species with the possible exception of $F$. rigescens increased in basal cover from the community site. Florez et al. (1985) reported that $F$. rigescens greened up about 2 weeks later and had lower protein content than other common cool season grasses in the Pampas Galeras Vicuna Reserve, also in the puna. These characteristics perhaps made it less palatable and allowed it to increase under the heavy grazing of the holding pasture. S. brachyphylla and Muhlenbergia ligularis (Hack) Hitchc. had an estimated basal cover in the holding pasture slightly higher than on the ranching cooperative. Florez et al. (1985) found that these 2 species had the highest crude protein contents and in vitro digestibility of any grasses evaluated in their study. C. vicunarum and C. ecuadorica were reported by Farfan and Bryant (1984) to be favored by alpaca during the dry season. These data suggest that survival of these species under heavy grazing is not due to inherent low palatability. Rather, it may be due to their ability to grow very close to the soil surface, providing protection to the apical meristem. Forb basal cover was about the same on the holding pasture as on the community site; however, there was a shifting of cover among the forb species. A. pinnata increased with cover while the other forb species decreased. Ability of forbs to tolerate heavy grazing pressure is also probably a result of their decumbent growth form rather than low palatability. In the altiplano, to the south, $A$. pinnata was a highly selected forage species during the dry season (Farfan and Bryant 1984).

Species diversity was higher on the community site than either the ranching cooperative or the holding pasture (Table 2). This was

Table 2. Simpsons D, Shannon-Weavers H', and species richness as indicators of species diversity for the cooperative, community site and holding pasture.

\begin{tabular}{lccc}
\hline \hline grasses & $\begin{array}{c}\text { Ranching } \\
\text { cooperative }\end{array}$ & $\begin{array}{c}\text { Community } \\
\text { site }\end{array}$ & $\begin{array}{c}\text { Holding } \\
\text { pasture }\end{array}$ \\
\hline $\mathrm{D}$ & 0.84 & 0.92 & 0.87 \\
$\mathrm{H}^{\prime}$ & 2.48 & 2.72 & 2.50 \\
Species richness & 10.9 & 13.5 & 10.5 \\
\hline
\end{tabular}

substantiated both by estimates of species diversity and species richness. The observed pattern of species diversity does not adhere to the classical view stating that diversity should increase with advancing succession (Bazzaz 1975, Whittaker 1972). Accordingly, species diversity should have decreased with grazing pressure. Whittaker (1972) did note, however, that climax communities sometimes have lower species diversity than immediately lower seral communities. Others have also observed a varied pattern of species diversity with succession (Denslow 1980, Drury and Nizbit 1973). The pattern observed here more closely follows Huston's (1979) dynamic equilibrium model for species diversity, which states that diversity is controlled by the rate of competitive displacement among species and forces that prevent equilibrium (any disturbance which reduces population size). Huston (1979) stated that the frequency of population reductions has a major effect on species diversity. His model predicts that for communities with low or intermediate growth rates (such as those of the puna), diversity will be reduced at high frequencies of disturbance (holding pasture) by the reduction or extinction of populations unable to recover from the disturbances. Also, at low frequencies of disturbance (ranching cooperative) diversity will be lower because of competitive displacement. Diversity is highest at intermediate frequency of disturbance (community site). Thus if one assumes that frequency and severity of grazing disturbance were low on the ranching cooperative, intermediate on the community site, and high on the holding pasture, then the dynamic equilibrium model for species diversity explains the pattern of diversity observed.

\section{Conclusions}

Reductions in standing height and biomass of the vegetation were the most obvious differences between the 3 compared areas. F. dolichophylla was most severely affected by grazing pressure. Generally basal cover of the other grass species were little affected by grazing pressures. $F$. rigescens increased with grazing pressure as did forbs. Ability of species to survive was not attributed to low species palatability but rather an ability to grow close to the soil surface.

Species diversity patterns were explained best by Huston's 
(1979) model for species diversity. Species diversity was highest on the community site, which experienced intermediate disturbance.

\section{Literature Cited}

Adams, S.N. 1975. Sheep and cattle grazing forests: A review. J. Appl. Ecol. 12:143-152.

Bazzaz, F.A. 1975. Plant species diversity in old field successional ecosystems in southern Illinois. Ecology 56:485-488.

Beek, J.K., and D.L. Bramao. 1968. Nature and geography of South American soils. In: E.J. Fittkav et al. (eds.) Biogeography and ecology in South America. W. Junk Press, the Hague.

Cabrera, A.L. 1968. Ecologia vegetal de la puna. In: C. Troll (ed.) Geoecology of the mountainous regions of the tropical Americas. Ferd Dummlers Verlag, Bonn.

Daubenmire, R. 1968. Plant communities: a textbook of plant synecology. Harper and Row, New York.

Denslow, J.S. 1980. Patterns of species plant diversity during succession under different disturbance regimes. Oecologia 46:18-21.

Drosdoff, M., F. Quevedo, C. Zamora. 1960. Soils of Peru. Trans. 7th Int. Congr. Soil Sci. 4:97-104.

Drury, W.H., and I.C.T. Nisbet. 1973. Succession. J. Arnold Arbol. 54:331-368.

Ellison, $L$. 1960. Influence of grazing on plant succession of rangelands. Bot. Rev. 26:1-78.

Engel, F.A. 1976. An ancient world preserved: relics and records of prehistory in the Andes. Crown Publishers, New York.

Farfan, R.D., and F.C. Bryant. 1984. Dry season forage selection by alpaca (Lama pacos) in southern Peru. J. Range Manage. 37:330-333.

Florez, A., E. Malpartida, F.C. Bryant, and E.P. Wiggers. 1985. Nutrient content and phenology of cool-season grasses of Peru. Grass and Forage Sci. 40:365-369.

Glaser, G., and J. Celecia. 1981. Guidelines for integrated ecological research in the Andean region. Mtn. Res. Dev. 1:171-186.

Goodall, D.W. 1952. Some considerations in the use of point quadrats for the analysis of vegetation. Aust. J. Sci. Res., Series B:1-41.

Greig-Smith, P. 1964. Quantitative plant ecology. 2nd ed. Butterworths, Washington.
Huston, M. 1979. A general theory of species diversity. Amer. Natur. 113:89-101.

Johnson, A.M. 1976. The climate of Peru, Boliva, and Ecuador. In: W. Schwerdtfeger (ed.) Climates of Central and South America. Elsevier Scientific, New York.

McBride, J.F. 1936. Flora of Peru. Field Mus. Natur. Hist. Bot. Ser., Pub. 351, Vol. 13. Chicago.

Molina, E.G., and A.V. Little. 1981. Geoecology of the Andes; the natural science basis for research planning. Mtn. Res. Dev. 1:115-144.

Peet, R.K. 1974. The measurement of species diversity. Ann. Rev. Ecol. Sys. 5:285-308.

Stoddart, L.A., A.D. Smith, and T.W. Box. 1975. Range management. McGraw-Hill, New York.

Thomas, R., and B.P. Winterhalder. 1976. Physiological and biotic environment of southern highland Peru. In: P.T. Baker and M.A. Little (eds.) Man in the Andes; a Multidisciplinary Study of High-altitude Quechua. Dowden, Hutchenson and Ross, Stroudsburg.

Tovar, 0. 1960. Revision de las especies Peruanas del genero Calamagrostis. Mem. Mus. His. "Javier Prado". No. 11. Lima.

Tovar, O. 1965. Revision de las especies Peruanas del genero Poa. Mem. Mus. His. Nat. "Javier Prado". No. 15. Lima.

Tovar, 0. 1972. Revision de las especies Pervanos de genero Festuca. Mem. Mus. His. Nat. "Javier Prado". No. 16. Lima.

Troll, C.C. 1968. The cordilleras of the tropical Americas; aspects of climate, phytogeographical and agrarian ecology. In: C. Troll (ed.) Geoecology of the mountainous regions of the tropical Americas. Ferd Dummlers Verlag, Bonn.

Vallejos, M., and H. Quillatupa. 1975. Manejo racional de las pasturas de la S.A.I.S. Pachacutec, basado en el mapeo-agrosto-edafologico. Tesis Ing. Zootecnista. Universidad National Agraria, La Molina, Lima.

Weberbauer, A. 1936. Phytogeography of the Peruvian Andes. In: J.F. McBride (ed.) Flora of Peru. Field Mus. Nat. His. Bot. Ser., Pub. 351, Vol. 13. Chicago.

Wilcox, B.P. 1982. Plant communities and soils of the central Andes of Peru. M.S. Thesis. Texas Tech University, Lubbock.

Whittaker, R.H. 1972. Evolution and measurement of species diversity. Taxon 21:213-251. 